\title{
Effect of Audit Quality on Non-Professional Investors Decisions: Experimental Evidence from Egypt
}

\section{Ibrahim $\mathbf{A}^{1,2}$ and Badawy $\mathbf{H}^{1,3^{*}}$}

${ }^{1}$ Faculty of Commerce, Alexandria University, Alexandria, Egypt

${ }^{2}$ University of Illinois at Urbana Champaign, USA

${ }^{3}$ Egypt Japan University for Science and Technology (E-JUST), Alexandria, Egypt

*Corresponding author: Badawy H, Faculty of Commerce, Alexandria University and Egypt Japan University for science and Technology (E-JUST), Alexandria, Egypt, Tel: +00201062272260; E-mail: heba.badawy@ejust.edu.eg

Received date: Oct 19, 2018; Accepted date: Oct 31, 2018; Published date: Nov 07, 2018

Copyright: (c) 2018 Ibrahim A et al. This is an open-access article distributed under the terms of the Creative Commons Attribution License, which permits unrestricted use, distribution, and reproduction in any medium, provided the original author and source are credited.

\begin{abstract}
Purpose of this paper: The purpose of this paper is to investigate non-professional investors' perceptions of audit quality proxied by audit firm size on their desirability to invest and their estimates of firm value.

Design/methodology/approach: Two within-subjects experiments were designed to test non-professional investors' perception regarding the impact of audit quality on their desirability to invest and their estimates of firm value in a single audit scenario and a joint audit scenario. Non-parametric statistical tests were used to test the research hypotheses.
\end{abstract}

Findings: In a single audit scenario, investors perceive a superior quality for the audit services provided by a big 4 versus a non-big 4 . In the case of a joint audit, the Accountability State Authority does not have the same superiority of audit quality versus a big 4 firm when it comes to Egyptian non-professional investors' perception for the audit quality provided.

Research limitations/implications: This paper uses postgraduate students that are registered in the financial accounting and auditing diploma in the faculty of commerce- Alexandria University as a proxy for non-professional investors. Real investors were difficult to recruit as subjects for the experiment conducted.

Social and practical implications: The results of the study imply a lower non-professional investors' perception for the quality of the audit services provided by the governmental body in Egypt, which is responsible for auditing all financial matters for governmental units. This result is alarming and needs immediate attention from the governmental bodies in Egypt.

What is original/value of paper? This paper is the first to examine the impact of audit quality on nonprofessional investors' desirability to invest and their estimates of firm value in Egypt. The paper focuses on the audit quality of the Accountability State Authority in comparison with that of the Big 4 firms, which was not examined before in Egypt. The paper contributes to the existing literature examining audit quality services in emerging markets.

Keywords: Audit quality; Non-professional investors' decisions; Joint audit; Big 4; Accountability state authority; Egypt

\section{Introduction}

Audit quality is a function of several variables; one of which is auditor independence. Theory suggests that the auditor's and the client's characteristics as well as the relationship between them are expected to influence audit quality. Measuring audit quality has been of extreme interest to accounting and auditing researchers as auditing is perceived as an independent assurance of the credibility of firms' reported information [1]. According to the agency theory, this states that the separation between ownership and management, and the resulting information asymmetry between preparers and users of information, has led to the demand for high quality audit. Prior literature discussed the main determinants of audit quality such as those relating to auditor's characteristics; expertise, knowledge, incentives, and to the task characteristics and the environment [2]. Being the main product of the auditing process, the standardized audit report has always been the subject of concern for prior literature. Because audit quality can't be observed directly, prior literature uses a large number of proxies to measure audit quality, even though there is no consensus on which measures are best [1]. This paper categorizes prior literature on audit quality into two main categories: The first group of studies focuses on the determinants/factors and indicators/ measures of audit quality. These can be classified mainly in three sub classifications to reflect auditors' characteristics, clients' characteristics, and finally the auditor-client contracting features. The second group of studies focuses mainly on the effect of high versus low audit quality on firm financials and decision makers. 
Although there are difficulties in defining audit quality [3], but the widely cited definition of audit quality by De Angelo [4] as the marketassessed joint probability that a given auditor will both:

- discover a breach in the client's accounting system, and

- report the breach broke down audit quality into two main components; the likelihood that an auditor discovers existing misstatements and the probability of reporting such a misstatement.

Although this definition is intuitive, it fails to highlight various factors that affect an auditor's capacity to detect misstatements. It also fails to introduce the concept of audit quality in terms of a continuum that can range from very low to very high quality levels. Since then, several attempts were conducted to introduce a definition for audit quality. Recently, Francis introduced a research-oriented framework of audit quality and argued that audit quality is a complex concept that is influenced by the analysis of the following six elements across a continuum [5]:

- Audit inputs

- Audit process

- Accounting firms

- Audit industry and audit markets

- Institutions

- Economic consequences of audit outcome.

More recently Knechel, Krishnan et al. summarize the concept of high audit quality as "one where there is execution of a well-designed audit process by properly motivated and trained auditors who understand the inherent uncertainty of the audit and appropriately adjust to the unique conditions of the client"[6]. In other words, they argue that all five attributes (i.e., process, incentive, judgment, uncertainty, and uniqueness) must be considered in measuring audit quality.

On the other hand, it is very important to emphasize that audit characteristics are not direct measures of audit quality, rather prior literature tests whether, for a given level of audit quality, there are systematic differences in audit outcomes (e.g., earnings quality) [6]. Since there is a belief that audit quality is perceived rather than directly observed, this paper focuses on how non-professional investors perceive audit reports issued by one of the Big 4 or non-big 4 or the Accountability State Authority in a different manner to the extent that it affects their investment decisions and valuation of firm value.

In this study, postgraduate students were used as surrogates for nonprofessional investors in an emerging capital market (Egyptian capital market). This paper examines whether they perceive differently the credibility of the audit report when prepared by a single audit firm; a big 4 firm versus a non-big 4 firm, and when prepared jointly; a big 4 firm and a non-big 4 firm versus a non-big four firm and the Accountability State Authority. Specifically, this paper examines whether non-professional investors are willing to revise their investment portfolio based on the issuer of the audit report (as a proxy for audit quality). This paper also examines whether differential audit quality reports cause non-professional investors to revise their judgments with respect to their firms' value estimates. This paper hypothesizes that non-professional investors will perceive audit reports prepared by a big- 4 firm to be of a higher quality in comparison with that of a non-big 4. And in the case of a joint audit, investors will perceive audit reports issued jointly by a non-big four firm and the Accountability State Authority to be of a higher quality in comparison with those prepared by a non-big 4 auditor and a big 4 one. This superiority is reflected on their desirability to invest and their firm valuation.

Prior literature seems to provide more evidence indicating that the audit quality of big 4 auditors is higher than that provided by non-big 4 auditors [7]. According to DeAngelo larger auditing firms are less likely than smaller auditing firms to compromise their independence, thus firm size proxies for audit quality [4]. Dopuch and Simunic argue that larger auditors provide higher quality services because they have greater reputation to protect [8]. Lawrence et al. propose that big 4 firms can provide higher quality audit as a result of their capability to support more robust training programs, more standardized audit methodologies, and more opportunities for second partner reviews [9].

The rich auditing setting that exists in the Egyptian capital market opens a new opportunity to extend this literature from just the traditional dichotomous split between big 4 versus non-big 4 , to a richer setting where this paper tests those two cases and also the case of joint reports issued by the main Governmental institution of monitoring fraud behavior. To do that, two within-subjects experiments were conducted, where the participants were introduced with basic financial information about a hypothetical firm and asked to indicate his/her level of confidence in the unaudited financials assuming that the value of the company's stock is at average. Then the fact that these financials were audited was introduced and the auditors' report was provided to all groups. The only difference will be the issuer of the audit report, where the first group is introduced with the single audit case, the report is signed by a non-big 4 audit firm and then by a big 4 audit firm, and the second group is introduced with the joint audit case, the report is signed jointly by a non-big 4 and a big 4 auditing firms and then by a non-big 4 and the Accountability State Authority.

The results of the study indicate a number of findings concerning how Egyptian non-professional investors perceive audit quality reflected in their desirability to invest in the firm and/or their value judgment for the firm. First, it is very clear that this type of investors value the audit services in general and they better perceive those firms that are audited by an accounting firm in general versus those reports provided to them without being audited at all. Second, in a single audit scenario, these non-professional investors perceive a superior quality for the audit service when a big 4 is the provider versus a non-big 4. Finally, in the case of a joint audit, the Accountability State Authority does not have the same superiority of audit quality versus a big 4 firm when it comes to Egyptian non-professional investors' perception of the quality of audit report provided.

The remainder of this paper is organized as follows: Section two, reviews the prior literature and develops the research hypotheses. Section three, describes the research design and experimental procedures. Section four, discusses the results of the experiment and its implications. Finally, section five concludes the study and provides suggestions for future research.

\section{Literature Review and Hypotheses Development}

Audit quality is by far one of the most thoroughly researched issues in the auditing literature. DeAnglo defined the quality of audit services as the market-assessed joint probability that a given auditor will both [4]:

- discover a breach in the client's accounting system, and 


\section{- report the breach.}

Also audit quality can refer to the auditor's process in conducting the audit in accordance to the Generally Accepted Auditing Standards to provide reasonable assurance that the financial statements are free from material misstatements [10]. Accordingly, it can be a determinant of financial reporting quality and has a considerable impact on the firm financials, which in turn will have a great effect on the investors' behavior and evaluation [2].

On the other hand, DeFond and Zhang argue that audit quality should be thought of as a continuum construct and not a binary process which limits the auditor's role to the simple detection and reporting of GAAP violations [1]. Thus they call for a definition of audit quality that incorporates the overall level of assurance of financial reporting quality, which extends beyond the mechanical judgment of the compliance with accounting standards. Accordingly, they define higher audit quality on page 279 as "greater assurance that the financial statements faithfully reflect the firm's underlying economics, conditioned on its financial reporting system and innate characteristics."

Prior audit quality literature focused mainly on addressing two main questions: the first is concerned with the measures of audit quality and the factors that may have an impact on the level of audit quality in general and from the investors' point of view in particular, i.e., how do we measure audit quality? The second is concerned with the impact of audit quality level on the firm's financials and other aspects, i.e., does audit quality really matter?

Audit quality measures examined in prior literature can be classified into two main classifications; input-based measures and output-based measures [1]. Inputs-based measures focus on the auditor's characteristics and the auditor-client contracting features, which assess audit quality using observable inputs to the audit process. These audit quality measures include auditor size, auditor independence, auditor competency and expertise, audit fees, and client innate characteristics. Output-based measures refer to those measures that are related to the output of the audit process and can be indicators of audit quality level. These measures include going concern opinions, misstatements and restatements, financial reporting quality, and exposure to litigation risks.

Audit firm size is by far the most widely used proxy for audit quality especially because it is known for its relatively high construct validity [1,11-14]. This proxy for audit quality is accepted from both audit partners' and well informed non-professional investors' point of views [15]. DeAnglo pointed that larger audit firms, measured by the number of clients, are more likely to present higher audit quality, as such firms don't depend mainly on the clients' fees for their existence [4]. In addition, it is assumed that big audit firms have more in-house experience and competencies in addition to large number of auditors and audit work hours that enable them to supply audit services of high quality [7]. Furthermore, according to the "Deep pocket" hypothesis, larger audit firms will be more likely to supply higher quality audits because they are subject more to litigation risk and can pay more $[1,16]$.

On the other hand, going concern opinions, and material restatements are considered very direct measures of audit quality [1]. This is because the failure to report a going concern when one is warranted is a clear indicator of poor audit quality evidenced by the auditor's issuance of the wrong audit opinion. Similarly, misstatements indicate that the auditor has issued an unqualified opinion on materially misstated financial statements. Financial reporting quality is considered a relatively less direct proxy for audit quality than the capturing audit failures measures because the auditor's influence on the client's financial reporting strategy is rather limited. Thus in the next few paragraphs the focus will be on audit quality measures in general and audit firm size in particular, and the impact of higher audit quality on firms' financials and investors decision.

\section{Single audit scenario}

Input-based measures of audit quality: In the public sector, prior research has investigated the effect of different factors on the audit quality level. Lowensohn et al. investigated the impact of auditor specialization on the level of audit quality and audit fees [17]. Based on a sample of 241 local government finance directors in Florida, USA, the authors found that auditor specialization has a positive effect on audit quality and not on audit fees. When Big audit firms are involved (as a proxy for audit quality), it was found that audit firm size is not associated all the time with higher audit quality but is always associated with higher audit fees.

Focusing on another factor affecting audit quality level, Elder, Lowensohn et al. investigated the impact of auditor rotation on audit quality using a sample of local governmental entities in Florida, USA [18]. They concluded that adopting rotation policies by auditors are more likely to have higher audit quality, however, when a specialist audit firm is involved, lower impact on audit quality was documented.

Bradbury focused on the audit fee premium associated with outsourcing public audit to private audit firms by comparing the audit fees between the governmental auditor and the big audit firms (Big 5) [19]. Based on a sample of public entities in New Zealand in the period of 1998 to 2000, the author found that there is a premium associated with the big audit firms, which may be because of technology. However, there is audit fee discount when the auditor involved is an industry specialist.

Output-based measures of audit quality: These measures capture audit failures in their diverse forms ranging from the extreme scenario of litigation against auditors to simple restatements and adjustments to previously issued financial statements. Successful litigation against auditors is very rare. This is because of the auditors' efforts to resolve disputes before they reach the formal stage of a lawsuit or even to settle out of court before these cases go to trial. Palmrose documented that the rate of litigation against auditors is less than 1 percent of audit engagements, and that the number of cases where the auditors were found guilty is even smaller $[20,21]$.

Another audit failure measure used in prior literature is the SEC's issuance of an enforcement action against an auditor. Although these enforcement actions are not a proof of audit failures, they are still infrequent. The number of annual SEC enforcement actions against auditors is also less than 1 percent of SEC registrants [22,23].

Going concern opinions are a third example of output-based audit quality measures, which refers to the failure to report a going concern when one is warranted. Such failure might be a clear indication of poor audit quality evidenced by the auditor's issuance of the wrong audit opinion. This error is referred to as Type 2 error (i.e., underqualifying), while Type 1 error (i.e., over-qualifying) refers to the auditor's issuance of a going-concern report when a client's failure does not take place within the following 12 months. Lennox documents that Big 4 auditors issue more accurate audit reports than do the non-Big 4 (fewer Type 1 and Type 2 errors)[24]. Big 4 firms are more likely to 
issue going concern opinions because they are better able to detect and issue such an opinion [7]. Although going-concern opinions are considered very direct measures of audit quality because the auditor's opinion is the auditor's direct communication with financial statement users and is under his/her control, they are relatively rare and exclusively issued to financially distressed clients [1]. On the other hand, while the literature provides evidence that audit quality is a main factor affecting the likelihood of going-concern opinions, there are other factors related to the auditor; such as auditor specialization and economic dependence, client; such as profitability and corporate governance and auditor client relationship; such as auditor switching and auditor-client tenure, that might interpret the issuance of going concern opinions [25]. More going-concern opinions may also reflect excessive auditor conservatism, which arguably reduces audit quality.

The aforementioned measures capture the actual audit quality, however, output based measures of audit quality include also perception based measures, which focus on the perceived audit quality. Basically, these measures focus on investors' beliefs and their perception of audit quality. These measures focus on the investor's reaction to different audit quality reports measured in terms of cost of capital, market price, earnings response coefficient, or simply their desirability to invest. These measures have a major advantage over input-based and output-based measures in that they are measures that are more comprehensive and capture collectively additional dimensions of audit quality than individual measures. Another major advantage of the perceived measures is that they overcome the problems of a binary approach in measuring audit quality simply as a dichotomy of either high or low audit quality [1]

Regarding the factors that may affect the level of audit quality, especially that from the investors' point of view, Dee, Lulseged et al. provided evidence that the disclosure of information about outsourced auditors have increased the level of transparency and provides investors with new information [26]. Such disclosures affect investors to the extent that it decreases the cumulative abnormal earnings and lowers the earnings response coefficient (as proxies for investors' perceived audit quality), especially for financially stressed and small issuers and those with lower expertise.

Additionally, in an experimental setting and using MBA students as surrogates to investors, Smith investigated the impact of the disclosure of two regulatory reforms on investors' perceived audit quality [27]. The first regulatory reform is concerned with a change in the approach for auditing internal controls from a bottom up coverage to a top down risk approach, while the second is concerned with a legal reform, which reduces the auditors' litigation exposure. The authors found that such changes have a negative impact on investors' perceived audit quality.

Audit quality influence on firms' financials: Prior literature has placed considerable attention on the impact of audit quality on firm financials, which in turn will have a great impact on investors' behavior and valuations. Prior literature examined such an impact and investigated whether the audit firm size (as a proxy for audit quality) will have an impact on the firms' cost of capital (debt or equity), earnings management, and propensity to issue going concern reports etc.

Regarding the impact of audit quality on the cost of capital, prior literature discussed the effect on cost of equity and cost of debt. Khurana and Raman investigated the impact of audit quality on the exante cost of equity in the U.S on one side versus Canada, U.K and
Australia on the other side, to identify whether the impact of firm size was due to litigation risk or for fear of losing their reputation [11]. The authors found evidence that the audit quality of the big 4 firms is derived from their fear from being sued and not from their protection to their reputation. Also, El Ghoul, Geudhami et al. found that the impact of audit quality is obvious in the environments, which are characterized by high investor protection and disclosure standards [28].

As for the impact on the cost of debt, prior literature supported the evidence that audit quality (as measured by audit firm size) has an impact on cost of debt. Firms that are audited by one of the big audit firms experienced reduction in the cost of borrowing when they seek financing. This evidence was clear in the case of young firms which went public and especially for young firms in the technology industry and older firms in the non-tech industry after IPO [13,29]. In Finland, where firms are obliged to be audited, Karjalainen found that the cost of borrowing was lower for those firms which are audited by multiple or certified auditors [30].

Accordingly, it is clear from the prior literature that the audit firm size (as a proxy for audit quality) has a negative impact on the cost of capital (debt and/or equity), and this implies that audit firm size is perceived to be an indicator of high quality from the point of view of lenders and investors.

In addition, audit quality has a considerable impact on management forecast accuracy and earnings management, which are very important issues from the investors' point of view, as firms that are audited by big auditors have lower earnings forecast bias and higher earnings forecast accuracy and that the earnings and book value of equity that are audited by big audit firms can explain the variations in stock return in comparison with those audited by non-big firms $[14,31]$.

Further, previous studies provided evidence on the negative impact of audit quality on discretionary accruals and the aggressiveness of management in earnings management. These studies found that higher quality auditors constrain managers' use of accruals, especially discretionary accruals [7,12,32].

Even for the financially distressed firms, Sundgren found evidence that audit firm size (as a proxy for audit quality) reduced the probability of filing for bankruptcy. This gives a positive signal regarding the management credibility even for firms, which are facing financial difficulties [33].

Additionally, prior research investigated the direct impact of audit quality on investors' trading volume, the return they require on their corporate bonds, and their ability to predict future earnings. It was found that investors appreciate higher quality auditors and asked for lower returns on their corporate bonds. In addition, investors have the ability to predict future earnings (two years ahead) when the firms are audited by one of the big audit firms [34]. Finally, Jang and Lin provided evidence that the trading volume of the 680 IPOs firms audited by one of the big firms was higher in the first day of trading but lower in later days when audited by one of the big audit firms compared with those audited by a non-big audit firm [35].

In summary, higher quality auditors constrain the aggressive use of accruals; especially discretionary ones to manage earnings and in turn this resulted in lower earnings management in comparison with those audited by non-big audit firms. Additionally, higher quality audits increase management forecast accuracy, lower the forecast bias, and increase the ability of earnings and book values of equity to explain the 
variations in stock return. Finally, investors' confidence in the financial statements increases when audited by one of the big audit firms and this leads to higher ability to predict future earnings and lower return demanded on corporate bonds and finally investors tend to increase their shareholdings from such type of firms.

While prior literature uses a large number of proxies to measure audit quality, there is no consensus on which measures are best, and little guidance is provided on how to evaluate the effectiveness of each of them. However, audit firm size remains to be the most widely used measure of audit quality in prior literature. Accordingly, this study hypothesizes that hiring one of the big audit firms gives a positive signal to the outside parties regarding the credibility of management and the issued financial statements, thus the first two hypotheses are:

H1: In case of a single audit, where the audit firm is a Big 4, investors' desirability to invest in the company increases in comparison with a single audit scenario with a non-Big 4 .

H2: In case of a single audit, where the audit firm is a Big 4, investors' valuation judgments of firm value will be higher compared to a single audit scenario with a non-Big 4 .

\section{Joint audit scenario}

There is a trend towards assigning more than one audit firm to perform the audit engagements, such audits may involve two big 4 firms, two non-big 4 firms or one big 4 and one non-big 4 firms. This is called joint audit, and might be used by some firms to signal higher audit quality to financial users. Ratzinger-Sakel et al. defined joint audit as "an audit in which financial statements are audited by two or more independent auditors in a way that involves: coordination of the audit planning; shared audit effort; cross reviews and mutual quality controls; and issuance of one single auditor's report signed by the auditors who are jointly liable [36]."

Regarding the advantages and disadvantages associated with joint audit, prior literature placed great attention on this debatable issue. Proponents of joint audit argued that joint audit approach achieves higher consensus and greater accuracy [37]. In addition, joint audit may have a positive impact on audit quality depending on the location of audit partners, as is the case when they are located in the same office. In such case, the joint audit will be more effective without an increase in cost as compared with employing single audit partners, when they are located in different audit offices, audit will be more efficient as cost will decrease slightly without a sacrifice in audit quality [38]. Finally, joint audit has a positive impact on shareholders' confidence [39] and a negative impact on the cost of equity and the implied cost of equity; however the investors' perception of the joint audit has been significantly mitigated if one of the two appointed auditors is a non-big 4 auditor [40]. To investigate the impact of joint audit from the investors' point of view in a developing country, Alfraih tested the effect of three pairs of auditors (two big 4, one big 4 and one non-big 4, and two non-big 4 audit firms) on firm value as measured by the value relevance of accounting information (earnings and book value) [41]. This study was applied in Kuwait, where joint audit is mandated for all listed firms in Kuwait Stock Exchange. Based on a sample of 1836 firm-year observations from 2002 to 2013, the study found a positive and significant effect of audit quality on the value relevance of earnings and book value. In addition, significant differences were found in the value relevance and book value across the three pairs of auditors.
On the other side, opponents of the joint audit approach justified their point of view and argued that joint audit is a net burden and does not make any difference in the auditors' ability to constrain earnings management [42]. In addition, joint audit is not associated with higher audit quality but it is associated with higher costs (audit or total fees) and does not have an impact on the value of the firm or auditor independence $[43,44]$. More than that, opponents found evidence, that joint audit that involves two Big 4 audit firms is associated with lower reporting quality. To justify their view, opponents argued that Big 4 audit firms apply comparable methodologies and bear comparable reputation risk, and when they work together, they would be probably rely on each other and, accordingly, would have fewer incentives to provide maximum effort [45]. Focusing on the impairment related disclosures, prior research found that a combination of Big 4/non-Big 4 auditors generates higher impairment-related disclosures levels in comparison with the combination of two Big 4 or two non-Big 4. Also, Big 4-Small auditor pairs book more timely impairments, manage less impairment tests' transparency and are more conditionally conservative than Big 4-Big 4 auditor pairs [46]. Finally, focusing on the free riding problem and that one of the audit firms may take advantage of the other audit firm's hard work, it was found that the total precision of audit evidence under joint audit (that involves Big 4/ Small audit firms) is lower than that under a single audit [47].

In summary, it is obvious that the impact of joint audit on audit quality and reporting is not clear. Part of the research supports the positive role that the joint audit plays in improving audit quality and shareholders' confidence and lowering the cost of capital. The other part argues that joint audit is a net burden and doesn't have an impact on audit quality or independence or auditors' ability to constrain earnings management and depending on the free riding problem is associated with lower precision of audit evidence. It is also clear that in case of impairment disclosures that the joint audit that includes two big 4 audit firms has less favorable impact on such disclosures in comparison with joint audit that includes one big 4 and one non big 4 and in the case of audit precision a single audit is more favorable than a joint audit that includes one big and one small audit firms.

\section{Auditing in the Egyptian environment}

In Egypt, there is the Accountability State Authority (ASA) which is an independent authority established in 1942 and reports to the president of the Arab Republic of Egypt. Its objective is to achieve effective control over state funds and funds of other public figures and other persons mentioned in the law. The ASA performs three types of control; financial control, performance control and control over employee affairs. This authority is made up of the head and his two deputies, agents and managers of the accounts control departments, control technicians and others who occupy regulatory and administrative positions. In addition to the financial control (with its accounting and legal components), the ASA has its role in controlling performance and monitoring the government's plan implementation and legal control over the decisions issued with respect to financial irregularities.

According to Law No. 144 for the year 1988, the ASA fulfills its role on different parties, such as bodies the constituents of the administrative body and the local government units, public bodies, public institutions and public sector bodies, unions and professional associations, political parties and national press institutions, and bodies that are under the supervision of the authority. In addition the Accountability State Authority has the right to fulfill its role in 
companies that are not considered public sector companies, but a public person or a public sector company or a public sector bank owns not less than $25 \%$ of its capital. These companies are required to prepare their financial statements using the same accounting standards as pure private firms and issue them at the end of each year. Here, ASA has the right to inspect any document or records or minutes of meeting that seems to be important in order to fulfill its role and has the right to inquire and keep any information that are considered necessary to the audit engagement. In this case, ASA performs its auditing engagement jointly with one of the big 4 firms or one of the non-big 4 firms. After completing the audit process, ASA issues a detailed report that shows the valuation and counting methods used by the entity and its compliance with the rules set the ASA, and the conclusions reached and whether the ASA has obtained all information required and deemed necessary and whether the balance sheet and final accounts represents fairly the real financial position of the company and the related budget or surplus at the end of the year.

It should be noted that the reporting of the ASA to the president and not a specific other authority enables it to fulfill its control role effectively and freely. In addition, this institution is committed currently and in the future to fulfill its role in accordance with the code and law. It is stuck to the objectives and the effective and prompt messages that enable it to achieve the objective of its establishment.

The financial statements of the companies listed in the Egyptian stock exchange are required to be audited, whether by a non-big 4 audit firm or a big 4 audit firm (for pure private companies not owned by the government) or by the ASA (for public companies owned totally by the government) or jointly by a big 4 and a non-big 4 (for pure private companies) or by big 4 and the ASA or by a non-big 4 and the ASA for companies that are owned partially (not less than 25\%) by a public person or a public sector company or a public sector bank.

From the discussion above, it is clear that ASA in Egypt is an independent body and reports to the president directly, and it adheres to strict rules to fulfill its control and auditing roles. In addition, the president of the ASA and its top executives are not subject to dismissal for any reason other than criminal actions where in this case very strict litigation procedures have to take place before the dismissal of any of these executives.

Because of the ASA's unique characteristics, it is believed that such auditing set up (i.e., complete independence with respect to audit fees and complete job protection) would add to the auditing engagement new dimensions to audit quality that has not been previously examined in prior literature, which focuses on the typical dichotomy of a Big versus non-Big audit firms. Accordingly, it is expected that ASA would provide higher audit quality services. Its role in auditing public companies is quite clear as it issues an audit report jointly with a nonbig 4 or a big 4 audit firms. To examine the joint audit scenario in Egypt, this paper's hypotheses and tests focus on the following two joint audit scenarios: the case of a Big 4 and non-big 4 versus joint audit case of a non-big 4 and the ASA. This is because this is the common scenario in Egypt and due to the disadvantages associated with the joint audit case that involves two big 4 audit firms.

Thus, the last two hypotheses can be stated as follows:

H3: In case of a joint audit, where one of the audit firms is a nonBig4 and the other one is the ASA, investors' desirability to invest in the company increases in comparison with a joint audit scenario with a non-big 4 and a big 4 .
H4: In case of a joint audit, where one of the audit firms is a nonBig4 and the other one is the ASA, investors' valuation judgments of firm value will be higher compared to a joint audit scenario with a non-big 4 and a big 4 .

\section{Research Methodology and Experimental Procedures}

\section{Participants}

The participants were 100 students registered in the financial accounting and auditing diploma in the faculty of commerce, Alexandria University. Students were used as surrogates for nonprofessional investors due to their sufficient knowledge in accounting and investing decisions $[48,49]$. In addition, prior literature provided evidence that students are suitable surrogates for practitioners taking short and long term decisions in an investment decision making tasks [50]. Also, they are suitable for studies that require cognitive abilities [48], and accordingly they are adequate proxies for non-professional investors who are taking investment decisions especially that it is difficult to have real investors to participate in the study [51]

\section{Design and manipulation}

Two within-subjects experiments were designed. The first one is for the single audit scenario (Experiment 1) and the second one is for the joint audit scenario (Experiment 2). Participants were presented with brief information on a hypothetical Egyptian company, Cooper Soda Co., which was identified as a leader in the premium soda category and known for its unique branding and innovative marketing. Because participants do not have enough information to evaluate the common stocks of the company, they were asked to assume that such a company is to be valued initially as an average one (at $\$ 50$ on a scale ranging from $\$ 0$ to $\$ 100$ ). Each experiment consisted of three sections. In the first section, participants were presented with information on the revenues and net profit of the 4th quarter of 2014 and the 4th quarter of 2015 and the change in revenues and net profit between the two quarters. This information was not audited at all in both experiments (refer to appendices A and B).

In the second section, participants were presented with the same information but in this case the information was being audited by one of the non-big 4 in the single audit scenario (single audit 1) (Experiment 1) and one of the non-big 4 and one of the big 4 firms in the joint audit scenario (joint audit 1) (Experiment 2). Then participants were allowed to answer the questions related after reading the information and were not allowed to return back to the previous page to ensure that previous responses are not changed (refer to appendices $\mathrm{A}$ and $\mathrm{B}$ ).

Finally, in the third section, participants were presented with the same information but this information was audited by one of the big 4 in the single audit scenario (single audit 2) (Experiment 1) and one of the non-big 4 firms and the Accountability State Authority in the joint audit scenario (joint audit 2) (Experiment 2). After each section, participants were asked to identify the type of auditor issuing the report if any, and the opinion presented in the report plus three additional questions asking them to rate their degree of reliability on the report provided, their desirability to buy the firm's stock, and finally to value the stock based on the report provided.

The single audit case includes the Big 4 and the non-big 4 firms and not the ASA, because it was assumed that the hypothetical company is a pure private company (not owned by the government or a public 
Citation: Ibrahim A, Badawy H (2018) Effect of Audit Quality on Non-Professional Investors' Decisions: Experimental Evidence from Egypt. Int J

Page 7 of 14

figure) in the single audit case, and a company that is partially owned company by the government in the joint audit case.

To assess the effectiveness of the audit report's issuer identity manipulation, participants were asked to identify the group to which the issuer of the audit report belongs. In the single audit report scenario $90 \%$ (37 out of 41 ) were able to correctly determine that no opinion was issued in the first section of the experiment, while 85\% (35 of 41) were able to correctly identify that the issuer of the audit report was a non-big 4 firm in the second section. Finally, $100 \%$ of the participants were able to correctly identify that the issuer of the audit report was a big 4 firm indicating a successful manipulation of the audit report issuer in the single audit scenario in all three sections (refer to the manipulation check question in all three sections in appendix A).

In the joint audit scenario, 93\% (40 out of 43) were able to correctly determine that no opinion was issued in the first section of the experiment. In the second section of this experiment $79 \%$ (34 of 43) were able to correctly identify that one of the issuers was a non-big 4 firm and $100 \%$ were able to determine that the second auditor was a big 4 firm. In the third section of this experiment, $81 \%$ (35 of 43 ) were able to correctly identify that one of the issuers was a non-big 4 firm, and $100 \%$ of the participants were able to identify the identity of the second issuer as the Accountability State Authority (refer to manipulation check question in all three sections in appendix B).

\section{Sample description}

Fifty copies of the single audit experiment and fifty copies of the joint audit experiment were distributed randomly on the students. After excluding observations that have missing values and those who answered the manipulation check questions incorrectly, the remaining usable observations were 41 single audit copies and 43 joint audit copes. In each experiment, the participants were asked at the end of each section to determine to what degree they can rely on the information presented and to indicate their desire to invest in Cooper Soda Co. based on the information provided. Finally they were asked to value the company's common stock on a scale ranging from low $(\$ 0)$ to high $(\$ 100)$. Refer to Table 1 for the descriptive statistics summarizing the participants' answers to these three questions in both experiments (Panel A for the single audit scenario and Panel B for the joint audit scenario).

\begin{tabular}{|c|c|c|c|c|c|c|c|}
\hline & Mean & St. dev. & Min & $\operatorname{Max}$ & 25th \% & Median & 75th \% \\
\hline \multicolumn{8}{|l|}{ No auditor opinion } \\
\hline Reliability & 2.73 & 0.95 & 1 & 4 & 2 & 3 & 3.5 \\
\hline Desirability to invest & 51.34 & 19.749 & 0 & 80 & 45 & 50 & 70 \\
\hline Firm valuation & 58.15 & 16.007 & 20 & 90 & 49 & 60 & 72.5 \\
\hline \multicolumn{8}{|l|}{ Non-big 4} \\
\hline Reliability & 3.76 & 0.888 & 2 & 5 & 3.5 & 4 & 4 \\
\hline Desirability to invest & 66.59 & 16.372 & 30 & 100 & 55 & 70 & 75 \\
\hline Firm valuation & 69.1 & 16.067 & 30 & 100 & 60 & 70 & 80 \\
\hline \multicolumn{8}{|l|}{ Big 4} \\
\hline Reliability & 4.61 & 0.586 & 3 & 5 & 4 & 5 & 5 \\
\hline Desirability to invest & 85.98 & 15.42 & 40 & 100 & 80 & 90 & 100 \\
\hline Firm valuation & 84.27 & 15.715 & 40 & 100 & 75.5 & 90 & 100 \\
\hline
\end{tabular}

Table 1a: Panel A: Single audit N=41.

\begin{tabular}{|c|c|c|c|c|c|c|c|}
\hline & Mean & St. dev. & Min & Max & 25th \% & Median & 75th \% \\
\hline \multicolumn{8}{|l|}{ No auditor opinion } \\
\hline Reliability & 2.33 & 0.993 & 1 & 4 & 2 & 2 & 3 \\
\hline Desirability to invest & 48.84 & 17.923 & 10 & 80 & 40 & 50 & 60 \\
\hline Firm valuation & 54.58 & 15.665 & 10 & 80 & 50 & 50 & 65 \\
\hline \multicolumn{8}{|l|}{ Non-big 4 \& Big 4} \\
\hline Reliability & 4.3 & 0.741 & 1 & 5 & 4 & 4 & 5 \\
\hline Desirability to invest & 79.3 & 16.532 & 30 & 100 & 70 & 80 & 90 \\
\hline
\end{tabular}




\begin{tabular}{|l|l|l|l|l|l|l|l|l|l|}
\hline Firm valuation & 77.79 & 12.924 & 40 & 100 & 75 & 80 & 90 \\
\hline Non-big 4 \& ASA & 4.12 & 0.905 & 1 & 5 & 4 & 4 & 5 \\
\hline Reliability & 73.6 & 21.446 & 20 & 100 & 60 & 75 & 90 \\
\hline Desirability to invest & 72.44 & 19.16 & 20 & 100 & 60 & 75 & 90 \\
\hline Firm valuation &
\end{tabular}

Table 1b: Panel B: Joint audit N=43.

Non parametric statistical tests were used in analyzing the data because the samples used were dependent and the independent variable (audit quality) is not a scale variable, but a nominal one. Friedman test was used to test for the statistical significance of the difference between the responses of the three dependent samples (no Audit-single audit 1-single audit 2) in the single audit scenario (Experiment 1). The same thing was conducted in the joint audit scenario (Experiment 2) across the three dependent samples (no Audit-joint Audit 1-Joint Audit 2). After ranking the three audit alternatives from the investors' point of view in each experiment, Wilcoxon Signed Ranks test was used to test for the statistical significance of the difference between each pair of audit alternatives.

\section{Statistical Results}

\section{Statistical analysis for $\mathrm{H} 1$ and $\mathrm{H} 2$}

The first 2 hypotheses are focusing on the single audit case in experiment 1 . The first hypothesis (H1) is testing the impact of choosing one of the Big 4 firms Vs non-big 4 firms to audit the financial statements of the company on the investors' desirability to invest.

\begin{tabular}{|l|l|l|l|l|l|l|}
\hline & Compared auditors & Mean rank & Rank result & N & Chi-square & p-value \\
\hline \multirow{3}{*}{ Reliability } & No audit opinion & 1.24 & 1 & & & \\
\cline { 2 - 7 } & Non-Big 4 & 1.99 & 2 & 41 & 57.881 & 0 \\
\cline { 2 - 7 } & Big 4 & 2.77 & 3 & & \\
\hline
\end{tabular}

Table 2: Friedman ranking test comparing the reliability on the information presented in the single audit scenario.

Statistical results of Friedman Test-as shown in Table 2; indicates that there are significant differences between the three audit choices which the company goes for. The three audit choices are 1- No Audit, 2- Audit by non-big 4 (Single audit 1), and 3- Audit by one of the Big 4 firms (Single audit 2). According to Friedman test results, and the mean ranks shown, the investors' desirability to invest will be at its highest level in case the company asks one of the Big 4 firms to audit its financial statements. In the second level, regarding the investors' desirability to invest comes the second audit choice which is the audit by one of the non-big 4 firms. Lastly, and in the third level is the alternative of not being audited at all, whether by one of the Big 4 or non-big 4 audit firms.
In order to illustrate whether there are significant differences between each pair of audit alternatives and specially the difference between the Big 4 and non-big 4 cases and test H1, Wilcoxon Signed Ranks Test was run on the data presented. This test is a non-parametric test used when comparing two dependent samples. In this case, this test is used to compare the responses of each pair of audit choices (No Audit Vs non-big 4-No Audit Vs Big 4-Big 4 Vs non-big 4).

The Wilcoxon signed ranks test results shown in Table 3 reveal that investors prefer to invest in companies that ask for audit services of one of the non-big $4(\mathrm{z}=-4.200$, $\mathrm{p}$-value $=0.000<a$ which is $2.5 \%)$ or Big $4(\mathrm{z}=-5.412, \mathrm{p}$-value $=0.000<\alpha$ which is $2.5 \%)$ audit firms in comparison with the no audit case.

\begin{tabular}{|l|l|l|l|l|}
\hline & Compared alternatives & Z statistic & p-value & Result of the test \\
\hline \multirow{3}{*}{ Reliability } & Non-Big 4 Vs No Audit opinion & -4.488 & 0 & \\
\cline { 2 - 6 } & Big 4 Vs No Audit opinion & -5.394 & 0 & \multirow{2}{*}{ H1 is supported } \\
\cline { 2 - 5 } & Big 4 Vs Non-Big 4 & -4.541 & 0 & \\
\hline
\end{tabular}

Table 3: Wilcoxon Signed Ranks test results comparing the reliability on the information presented in the single audit scenario.

In addition, the test results reveal that the investors' desirability to invest increase for companies being audited by one of the Big 4 firms in comparison with the case of non-big 4 firms ( $\mathrm{z}=-4.895$, p- value $=0.000<\alpha$, which is $2.5 \%$ ). Again this result goes with the Friedman test results in Table 2 that Big 4 firms are better in quality than non-Big 4 in their impact on the investors' desirability to invest in 
companies. This result provides additional evidence to the literature review that high quality audit adds value to information from the investors' point of view [41]. Accordingly, H1 was supported.

\begin{tabular}{|l|l|l|l|l|l|l|}
\hline & Compared auditors & Mean rank & Rank result & N & Chi-square & p-value \\
\hline \multirow{3}{*}{ Desirability to invest } & No audit opinion & Non-Big 4 & 1.24 & 1 & & \\
\cline { 2 - 6 } & Big 4 & 1.91 & 2 & 41 & 60.097 & 0 \\
\hline
\end{tabular}

Table 4: Results of Friedman Ranking test comparing the desirability to invest in the single audit scenario.

The second hypothesis $(\mathrm{H} 2)$ is formulated to test the impact of choosing between the Big 4 and Non Big 4 firms on the investors' valuation of the companies' shares. To test this hypothesis, Friedman test and Wilcoxon Signed Ranks Test were used. The Friedman test results shown in Table 4 shows significant differences between the three audit choices on the investors' valuation of the companies' shares (Chi-square $=52.778, \mathrm{p}$-value $=0.000$ ). The results showed that investors ranked the alternative of Big 4 firms the highest (Mean rank=2.73), and then the non-big 4 (Mean rank=1.94) and at the last level is the choice of not being audited at all (Mean rank=1.33). This result is consistent with the results of $\mathrm{H} 1$, where investors' perception towards the companies' financial statements differs when such statements are not being audited, or audited by one of the Big 4 or Non Big 4 audit firms.

Accordingly, it is clear that the investors' valuation of the companies' shares differs significantly under the three audit cases.

In order to test the second hypothesis $(\mathrm{H} 2)$ and identify whether there are significant differences between the investors' valuation of the companies being audited by one of the Big 4 firms in comparison with the one of the non-big 4 firms, Wilcoxon signed ranks test is used.

\begin{tabular}{|l|l|l|l|l|}
\hline & Compared alternatives & Z statistic & p-value & Result of the test \\
\hline \multirow{3}{*}{ Desirability to invest } & Non-Big 4 Vs No Audit opinion & -4.2 & 0 & \\
\cline { 2 - 5 } & Big 4 Vs No Audit opinion & -5.412 & 0 & \multirow{2}{*}{ H2 is supported } \\
\cline { 2 - 5 } & Big 4 Vs Non-Big 4 & -4.895 & 0 & 0 \\
\hline
\end{tabular}

Table 5: Wilcoxon Signed Ranks test results comparing the desirability to invest in the single audit scenario.

The results of Wilcoxon signed ranks test presented in Table 5 shows that investors will value the companies' shares highly in case being audited by one of the Big $4(\mathrm{z}=-5.031$, $\mathrm{p}$-value $=0.000<\mathrm{a}$ which is $2.5 \%)$ or the non-big $4(\mathrm{z}=-4.025$, $\mathrm{p}$-value $=0.000<\alpha$, which is $2.5 \%)$ audit firms in comparison with the no audit case.

Wilcoxon Signed ranks test is also used to compare the investors' valuation of the companies' shares, when being audited by one of the Big 4 in comparison with being audited by one of the non-big 4 . The results shown in Table 5 provides evidence that investors valuation to the companies' shares will be higher in case being audited by one of the Big 4 firms in comparison with being audited by one of the non-big 4 firms. Accordingly, $\mathrm{H} 2$ was supported.

This result indicates that investors appreciate the companies' choice of one of the Big 4 firms to audit their financial statements. The statistical result is consistent with prior studies which note that Big 4 firms provide high audit quality services because they have better in house experience and more auditors with high level of competencies [7]. This result provides evidence that the audit firm size is a proxy for audit quality.

\section{Statistical analysis for $\mathrm{H} 3$ and $\mathrm{H} 4$}

The third and fourth hypotheses deal with the joint audit case, where there are two alternatives in front of the company, either to ask for an audit performed jointly by one of the Big 4 and one of the nonbig 4 audit firms (Joint audit 1) or to be audited by one of the non-big 4 audit firms and the Accountability State Authority (ASA) (Joint Audit 2).

The third hypothesis (H3) is formulated to test whether investors prefer and have desire to invest in companies audited by the joint audit 1 case (non-Big 4 and Big 4) in comparison with the joint audit 2 case (non-Big 4 and the Accountability State Authority).

\begin{tabular}{|l|l|l|l|l|l|l|}
\hline & Compared auditors & Mean rank & Rank result & N & Chi-square & p-value \\
\hline \multirow{2}{*}{ Firm valuation } & No audit opinion & 1.33 & 1 & 41 & 52.778 & 0.000 \\
\cline { 2 - 5 } & Non-Big 4 & 1.94 & 2 & & \\
\hline
\end{tabular}


Citation: Ibrahim A, Badawy H (2018) Effect of Audit Quality on Non-Professional Investors' Decisions: Experimental Evidence from Egypt. Int J Account Res 6: 185. doi:10.4172/2472-114X.1000185

Page 10 of 14

$\operatorname{Big} 4$

2.73
3

Table 6: Results of Friedman Ranking test comparing the firm valuation in the joint/dual audit scenario.

Friedman Test results presented in Table 6 shows that investors' desirability to invest differ significantly between the three audit choices (Chi-square $=44.844$, $\mathrm{p}$-value $=0.000$ ). The no audit choice was ranked the last (Mean rank=1.28), while the joint audit (1) case is ranked the highest (Mean rank=2.50) and the joint audit (2) case is ranked the middle (Mean rank=2.22).
This result indicates that investors' desirability to invest increases in case the financial statements being audited jointly by one of the Big 4 and one of the non-big 4 (joint audit 1 case) than when it is audited jointly by one of the non-big 4 and the Accountability State Authority (ASA) (joint audit 2 case).

\begin{tabular}{|l|l|l|l|l|}
\hline & Compared alternatives & Z statistic & p-value & Result of the test \\
\hline \multirow{3}{*}{ Firm valuation } & Non-Big 4 Vs No Audit opinion & -4.025 & 0 & \\
\cline { 2 - 5 } & Big 4 Vs No Audit opinion & -5.031 & 0 & \\
\cline { 2 - 5 } & Big 4 Vs Non-Big 4 & -4.264 & 0 & H3 is supported \\
\hline
\end{tabular}

Table 7: Wilcoxon signed ranks test results comparing the firm valuation in the single audit scenario.

However, in order to test for the statistical significance between each pair of audit alternatives, Wilcoxon signed ranks test was being used. The results of such test presented in Table 7, show that investors' desirability to invest increase in the case of joint audit, whether joint audit $1(\mathrm{z}=-5.354, \mathrm{p}$-value $=0.000<\alpha$, which is $2.5 \%)$ or joint audit 2 $(\mathrm{z}=-4.583$, p-value $=0.000<\alpha$, which is $2.5 \%)$ that when the financial statements are not being audited at all.

The results also show the investors' preference of the joint audit 1 case over the joint audit 2 case $(\mathrm{z}=-2.254$, $\mathrm{p}$-value $=0.024<\alpha$, which is
0.025) which is reflected on their desirability to invest. This indicates investors' valuation of audit quality of the Big 4 firms in comparison with that of the Accountability State Authority. Accordingly, H3 can't be supported.

As for the fourth hypothesis (H4), it is formulated to test whether investors' valuation of the companies' shares increases when such companies are audited jointly by one of the non-big 4 and the Accountability State Authority (ASA) (joint audit 2) than when audited by one of the Big 4 and one of the non-big 4 audit firms (joint audit 1).

\begin{tabular}{|l|l|l|l|l|l|l|}
\hline & Compared auditors & Mean rank & Rank result & N & Chi-square & p-value \\
\hline \multirow{3}{*}{ Reliability } & No audit opinion & 1.16 & 1 & & \\
\cline { 2 - 7 } & Joint audit (Big 4-Non Big 4) & 2.48 & 3 & 43 & 57.97 & 0 \\
\cline { 2 - 6 } & Dual audit (Non Big 4-ASA) & 2.36 & 2 & & \\
\hline
\end{tabular}

Table 8: Results of Friedman Ranking test comparing the reliability on the information presented in the joint/dual audit scenario.

Friedman test results in Table 8 show the mean ranks of each alternative. This result indicates that there are significant differences between the three audit alternatives in their impact on the investors' valuation of the companies' shares (Chi-square $=41.511, \mathrm{p}$ - value $=0.000$ ). In addition to the results presented in Table 8 show that investors' valuation of the companies' shares is affected highly by the joint audit 1 case (Mean rank $=2.50$ ) and then the joint audit 2 case (Mean rank=2.17) and lastly by the no audit case (Mean rank=1.33).

\begin{tabular}{|l|l|l|l|l|}
\hline & Compared alternatives & Z statistic & p-value & Result of the test \\
\hline \multirow{3}{*}{ Reliability } & Joint audit (Big 4 - Non Big 4) Vs No audit opinion & -5.412 & 0 & \\
\cline { 2 - 6 } & Dual audit (Non Big 4 - ASA) Vs No audit opinion & -5.27 & 0 & \\
\cline { 2 - 5 } & Dual audit (Non Big 4 - ASA) Vs Joint audit (Non Big 4-Big 4) & -1.33 & 0.183 & H4 is not supported \\
\hline
\end{tabular}

Table 9: Wilcoxon Signed Ranks test results comparing the reliability on the information presented in the joint/dual audit scenario.

To test the fourth hypothesis, Wilcoxon signed ranks test is used to assess whether there are significant differences between each pair of audit alternatives. Statistical results shown in Table 9 indicate that investors' valuation of the companies' shares will increase in case of joint audit [whether the joint audit 1 case $(\mathrm{z}=-5.173$, $\mathrm{p}$-value $=0.000<\alpha$, which is $2.5 \%)$ case or the joint audit 2 case $(\mathrm{z}=-3.984$, $\mathrm{p}$-value $=$ $0.000<a$, which is $2.5 \%$ )] than in the case of no audit. However, the statistical results doesn't show significant differences between the two 
Page 11 of 14

joint audit cases in their impact on the investors' valuation of the companies' shares $(\mathrm{z}=-1.950, \mathrm{p}$-value $=0.051>\alpha$, which is $2.5 \%)$ although Friedman test results in Table 8 show that the joint audit 1 case is higher than the joint audit 2 case in its impact. Accordingly, $\mathrm{H} 4$ is not supported.

\section{Additional analyses}

Because these two experiments are within-subjects experiments and participants might be biased in their responses and because of learning effects, two additional analyses were made. The first additional analysis is concerned with the single audit scenario and the related hypotheses ( $\mathrm{H} 1$ and $\mathrm{H} 2$ ). This analysis focuses on the differences between the responses of the first group (single audit scenario) towards the non-big 4 case and the responses of the second group (joint audit scenario) towards the joint audit case 1 (Big 4 and non-big 4 ) in order to identify whether there is an additional value of having a big 4 firm in the audit engagement in comparison with not having it. Mann Whitney test was being used to test the significance of differences between the two independent groups. Statistical results in Table 10 showed significant differences between group 1 (non-big 4) and group 2 (big 4 and nonbig 4) in their reliance on the audited information ( $Z=-3.165$, $p$ value $=0.002<\alpha$, which is $2.5 \%$ ). Participants' reliance on the audited information is higher in the case the audit report is issued by one of the big 4 (Mean rank=49.77) than when it is issued by one of the non-big 4 (Mean rank=34.88). Same results were shown when investors tend to show their desire to invest in Cooper Soda Co. and their valuation of the common stocks of the company. Investors' desire to invest in Cooper Soda Co. differs significantly $(Z=-3.798, p$-value $=0.000<\alpha$, which is $2.5 \%$ ) and is higher when the information is being audited by one of the big 4 (Mean rank=52.28) than when it is audited by one of the non-big 4 (Mean rank=32.24). Also, investors' valuation of the common shares differs significantly in case the audit report is issued by one of the big- 4 than when it is issued by one of the non-big 4 $(\mathrm{Z}=-2.945$, $\mathrm{p}$-value $=0.003<\alpha$, which is 0.025$)$. Investors' valuation of common shares increases in case of big 4 firm was higher (Mean rank=50.06) in comparison with the case of non-big 4 (34.57).

\begin{tabular}{|l|l|l|l|l|l|l|}
\hline & Compared auditors & Mean rank & Rank result & N & Chi-square & p-value \\
\hline \multirow{4}{*}{ Desirability to invest } & No audit opinion & 1.28 & 1 & & & \\
\cline { 2 - 7 } & Joint audit (Big 4-Non Big 4) & 2.5 & 3 & 43 & 44.844 & 0 \\
\cline { 2 - 7 } & Dual audit (Non Big 4-ASA) & 2.22 & 2 & & & \\
\hline
\end{tabular}

Table 10: Results of Friedman Ranking test comparing the desirability to invest in the joint/dual audit scenario.

Accordingly, same conclusions were reached regarding the single audit scenario and can say that investors' desirability to invest in the company has increased in case its financial information is being audited by one of the big 4 firms in comparison with the case of the non-big 4 firms (H1 is supported). In addition, results confirmed prior results regarding investors' higher firm valuation in case of big 4 firms in comparison with the non-big 4 firms (H2 is supported).

\begin{tabular}{|l|l|l|l|l|}
\hline & Compared alternatives & Z statistic & p-value & Result of the test \\
\hline \multirow{3}{*}{ Desirability to invest } & Joint audit (Big 4-Non Big 4) Vs No audit opinion & -5.354 & 0 & \\
\cline { 1 - 4 } & Dual audit (Non Big 4-ASA) Vs No audit opinion & -4.583 & 0 & H5 is not supported \\
\cline { 1 - 4 } & $\begin{array}{l}\text { Dual audit (Non Big 4-ASA) Vs Joint audit (Non } \\
\text { Big 4-Big 4) }\end{array}$ & -2.254 & 0.024 & (n) \\
\hline
\end{tabular}

Table 11: Wilcoxon Signed Ranks test results comparing the desirability to invest in the joint/dual audit scenario.

The second additional analysis is conducted to verify the impact of having the ASA in the joint audit scenario in comparison of not having it at all. This analysis focuses on the differences between the responses of the first group (single audit scenario) towards the non-big 4 case and the responses of the second group (joint audit scenario) towards the joint audit case 2 (non-big 4 and Accountability State Authority). Mann Whitney test was being used to test the significance of differences between the two independent groups. Statistical results in Table 11 showed no significant differences between group 1 (non-big 4) (Mean rank=37.50) and group 2 (non-big 4 and ASA) (Mean rank $=47.27)$ in their reliance on the audited information $(Z=-2.006, p-$ value $=0.045>\alpha$, which is $2.5 \%$ ). Same results were shown when investors tend to show their desire to invest in Cooper Soda Co. and their valuation of the common stocks of the company. Investors' desire to invest in Cooper Soda Co. doesn't differ significantly $(\mathrm{Z}=-2.080$, $\mathrm{p}-$ value $=0.037>\alpha$, which is $2.5 \%$ ) when the information is being audited by one of the non-big 4 (Mean rank=39.18) than when it is audited by the ASA (Mean rank=45.66). Also, investors don't show significant differences in their valuation of the common shares in case the audit report is issued by one of the non-big- 4 than when it is issued by the ASA ( $\mathrm{Z}=-1.227$, $\mathrm{p}$-value $=0.220>\alpha$, which is $2.5 \%)$. Investors' valuation of common shares doesn't differ significantly between the two cases.

\section{Conclusions and Implications for Future Research}

Auditing has always been perceived as an integral part of the capital markets. Regulatory bodies such as the SEC and the AICPA on one hand, and academic researchers and practitioners on the other hand have all emphasized the importance of high quality audits for the proper functioning of capital markets. This study examines nonprofessional investors' perception of the audit quality when different providers of the audit service conduct the audit and how does this 
Citation: Ibrahim A, Badawy H (2018) Effect of Audit Quality on Non-Professional Investors' Decisions: Experimental Evidence from Egypt. Int J

reflect on their judgments of the firm value and on their investment decisions (Table 12).

\begin{tabular}{|l|l|l|l|l|l|l|}
\hline & Compared auditors & Mean rank & Rank result & N & Chi-square & p-value \\
\hline \multirow{4}{*}{ Firm valuation } & No audit opinion & 1.33 & 1 & & & \\
\cline { 2 - 7 } & Joint audit (Big 4-Non Big 4) & 2.5 & 3 & 43 & 41.511 & 0 \\
\cline { 2 - 7 } & Dual audit (Non Big 4-ASA) & 2.17 & 2 & & & \\
\hline
\end{tabular}

Table 12: Results of Friedman Ranking test comparing the firm valuation in the joint/dual audit scenario.

The paper conducted two experiments. In the first experiment the paper replicated the traditional big- 4 versus non-big 4 test to show that investors perceive the audit quality provided by a big 4 firm to be superior over that provided by a non-big 4 . In the second experiment (the joint audit scenario) the study examined how non-professional investors in Egypt perceive the audit quality of an audit report provided jointly by a non-big 4 firm and the Accountability State Authority versus that provided jointly be a non-big 4 firm and a big 4 firm (Table 13).

\begin{tabular}{|l|l|l|l|l|}
\hline & Compared alternatives & Z statistic & p-value & Result of the test \\
\hline \multirow{4}{*}{ Firm valuation } & Joint audit (Big 4-Non Big 4) Vs No audit opinion & -5.173 & 0 & \\
\cline { 2 - 5 } & Dual audit (Non Big 4-ASA) Vs No Audit opinion & -3.984 & 0 & H6 is not supported \\
\cline { 2 - 5 } & $\begin{array}{l}\text { Dual audit (Non Big 4-ASA) Vs Joint audit (Big 4-Non Big } \\
\text { 4) }\end{array}$ & -1.95 & 0.051 & (n) \\
\hline
\end{tabular}

Table 13: Wilcoxon Signed Ranks test results comparing the firm valuation in the joint/dual audit scenario.

\begin{tabular}{|c|c|c|c|c|}
\hline & & Z statistic & p-value & Result of the test \\
\hline \multirow{3}{*}{$\begin{array}{l}\text { Non-Big } 4 \text { (single audit) Vs Non-Big } 4 \text { and Big } 4 \text { (joint } \\
\text { audit) }\end{array}$} & Reliability & -3.165 & 0.002 & $\mathrm{H} 1$ is supported \\
\hline & Desirability to invest & -3.798 & 0 & $\mathrm{H} 2$ is supported \\
\hline & Firm valuation & -2.945 & 0.003 & $\mathrm{H} 3$ is supported \\
\hline
\end{tabular}

Table 14: Mann Whitney test results comparing between the single audit case (non-big 4) and the joint audit case.

The results indicate that when a single auditor is conducting the audit, investors in the Egyptian capital market increase their firm valuations and have more desire to invest in those firms audited by a big 4 firm over those audited by a non-big 4 firm, which is generally consistent with prior research findings (Table 14).

\begin{tabular}{|l|l|l|l|}
\hline & & Z statistic & p-value \\
\hline \multirow{4}{*}{$\begin{array}{l}\text { Non-Big } 4 \text { (single audit) Vs Non-Big 4 and ASA (Dual } \\
\text { audit) }\end{array}$} & Reliability & -2.006 & 0.045 \\
\cline { 2 - 5 } & Desirability to invest & -2.08 & 0.037 \\
\cline { 2 - 4 } & Firm valuation & -1.227 & 0.22 \\
\hline
\end{tabular}

Table 15: Mann Whitney test results comparing between the single audit case (non-big 4) and the dual audit case.

Surprisingly, no evidence was found to support the belief that when a joint audit is selected, the Accountability State Authority has a superior perception by Egyptian investors neither in terms of their desirability to invest nor in terms of their desirability to revalue the firm over big 4 auditors. This result open the way for a steam of future research to either support or dispute this finding in other countries where a similar governmental agency having the same features as the Accountability State Authority in Egypt exists as is the case in Saudi Arabia, Kuwait, and Qatar. If similar results are documented in other countries then the effectiveness of such governmental agencies will be questioned. If similar results are not documented in other countries, then future research needs to explore the various reasons for such behavior by Egyptian investors. (Table 15).

\section{References}

1. DeFond M, Zhang J (2014) A Review of Archival Auditing Research. J Acc Econ 58: 275-326. 
2. Gaynor L, Kelton A, Mercer M, Yohn T (2016) Understanding the Relation between Audit Quality and Financial Reporting Quality Auditing. J Pract Theory 35: 1-22.

3. Bedard J, Johnstone K, Smith E (2010) Audit quality indicators: A status update on possible public disclosures and insights from audit practice. Current Issues in Auditing 4: 12- 19.

4. DeAnglo L (1981) Auditor Size and Audit Quality. J Acc Econ 3: 183-199.

5. Francis J (2011) A Framework for Understanding and Researching Audit Quality Auditing. J Pract Theory 30: 125-152.

6. Knechel R, Krishnan G, Pevzner M, Shefchik L, Velury U (2013) Audit quality: Insights from the academic literature Auditing. J Pract Theory 32: 385-421.

7. Francis J, Yu M (2009) Big 4 Office Size and Audit Quality. The Accounting Review 84: 1521-1552.

8. Dopuch N, Simunic D (1980) The Nature of Competition in the Auditing Profession: A Descriptive and Normative View. In Regulation and Accounting Profession 34: 283-289.

9. Lawrence A, Minutti MM, Zhang P (2011) Can Big 4 versus Non-Big 4 differences in Audit-Quality Proxies be Attributed to Client Characteristics? The Accounting Review 86: 259-286.

10. US General Accountability Office (US GAO) (2004) Mandatory Audit Firm Rotation Study: Study Questionnaires, Responses, and Summary of Respondents' Comments, (GAO-04-217). Washington, DC: U.S. General Accountability Office.

11. Khurana I, Raman K (2004) Litigation Risk and the Financial Reporting Credibility of Big 4 versus Non-Big 4 Audits: Evidence from AngloAmerican Countries. The Accounting Review 79: 473-495.

12. Chen H, Chen J, Lobo G, Wang Y (2011) Effects of Audit Quality on Earnings Management and Cost of Equity Capital: Evidence from China. Contemp Acc Res 28: 892-925.

13. Causholli M, Knechel W (2012) Lending Relationships, Auditor Quality and Debt Costs. Managerial Auditing Journal 27: 550-572.

14. Lee H, Lee H (2013) Do Big Audit Firms Improve the Value Relevance of Earnings and Equity? Managerial Auditing Journal 28: 628-646.

15. Christensen B Glover S, Omer T, Shelley M (2016) Understanding Audit Quality: Insights from Audit Partners and Investors. Contemp Acc Res 33: $1648-1684$.

16. Lennox C (1999a) Audit Quality and Auditor Size: An Evaluation of Reputation and Deep Pocket Hypotheses. J Bus Finance Acc 26: 779-805.

17. Lowensohn S, Johnson L, Elder R, Davies S (2007) Auditor specialization, perceived audit quality, and audit fees in the local government audit market. J Acc Public Policy 26: 705-732.

18. Elder R, Lowensohn S, Reck J (2015) Audit Firm Rotation, Auditor Specialization, and Audit Quality in the Municipal Audit Context. J Gov Nonprofit Acc 4: 73-100.

19. Bradbury $\mathrm{M}$ (2015) Large audit firm premium and audit specialization in the public sector. Accounting and Finance.

20. Palmrose ZV (1987) Litigation and Independent Auditors: The Role of Business Failures and Management Fraud Auditing. J Pract Theory 6: 90-103.

21. Palmrose ZV (1988) An analysis of Auditor Litigation and Audit Service Quality. The Accounting Review 63: 55-73.

22. Feroz E, Park K, Pastena V (1991) The Financial and Market Effects of the SEC's Accounting and Auditing Enforcement Releases", J Acc Res 29: 107-142.

23. Dechow P, Hutton A, Sloan R (1996) Causes and Consequences of Earnings Manipulation: An Analysis of Firms' Subject to Enforcement Actions of the SEC. Contemp Acc Res 13: 1-36.

24. Lennox C (1999b) Are Large Auditors more Accurate than Small Auditors? Acc Bus Res 29: 217-227.

25. Carson E, Fargher N, Geiger M, Lennox C, Raghunandan K, et al. (2013) Audit Reporting for Going Concern Uncertainty: A Research Synthesis, Auditing. J Pract Theory 32: 353-384.
26. Dee C, Lulseged A, Zhang T (2015) Who Did the Audit? Audit Quality and Disclosures of Other Audit Participants in PCAOB Filings. Acc Rev 90: 1939-1967.

27. Smith J (2012) Investors' Perceptions of Audit Quality: Effects of Regulatory Change Auditing. J Pract Theory 31: 17-38.

28. El Ghoul S, Guedhami O, Pittman J (2011) Cross-Country Evidence on the Importance of Big Four Auditors to Equity Pricing: The Mediating Role of Legal Institutions.

29. Pittman J, Fortin S (2004) Auditor Choice and the Cost of Debt Capital for Newly Public Firms. J Acc Econ 37: 113-136.

30. Karjalainen J (2011) Audit Quality and Cost of Debt Capital for Private Firms: Evidence From Finland. Int J Auditing 15: 88-108.

31. Karim A, Ahmed K, Hasan $T$ (2013) Impact of audit quality and ownership structure on the bias and accuracy of earnings forecasts issued in IPO prospectuses: Evidence from a frontier market. Studies in Economics and Finance 30: 288-316.

32. Becker C, Defond M, Jiambalvo J, Subramanyam K (1998) The Effect of Audit Quality on Earnings Management. Contemp Acc Res 15: 1-24.

33. Sundgren S (2009) Perceived Audit Quality, Modified Audit Opinions and the Likelihood of Liquidating Bankruptcy among Financially Weak Firms. Int J Auditing 13: 203-221.

34. Hussainey K (2009) The impact of audit quality on earnings predictability. Managerial Auditing Journal 24: 340-351.

35. Jang HY, Lin CJ (1993) Audit Quality and Trading Volume Reaction: A Study of Initial Public Offering of Stocks. J Acc Public Policy 12: 263-287.

36. Ratzinger-Sakel N, Audousset-Coulier S, Kettunen J, Lesage C (2013) Joint Audit: Issues and Challenges for Researchers and Policy-Makers. Acc Eur 10: 175-199.

37. Baldauf J, Steckel R (2012) Joint Audit and Accuracy of the Auditor's Report: An Empirical Study. International J Econ Sci Appl Res 5: 7-42.

38. Ittonen K, Tronnes P (2015) Benefits and costs of appointing joint audit engagement partners Auditing. J Pract Theory 34: 23-46.

39. Benali A (2013) The Shareholders Confidence and Effectiveness of the Joint Auditors: Empirical Validation in the French Context. Int J Bus Manage 8: 76-84.

40. Alsadoun N, Aljabr Y (2014) Joint Audit and Cost of Equity Capital: Evidence from Saudi Arabia.

41. Alfraih M (2016) The Role of Audit Quality in Firm Valuation: Evidence from an Emerging Capital Market with a Joint Audit Requirement. Int J Law Manage 58: 575-598.

42. Holm C, Thinggaard F (2010) Joint audits-benefit or burden?

43. Lesage C, Ratzinger-Sakel N, Kettunen J (2017) Consequences of the Abandonment of Mandatory Joint Audit: An Empirical Study of Audit Costs and Audit Quality Effects. Eur Acc Rev 26: 311-339.

44. Khatab G (2013) The Effect of Joint Audit and Audit Rotation on the Firm's Value. Int Bus Res Conf.

45. Marmousez S (2009) The choice of joint-auditors and earnings quality: Evidence from French listed companies. Canadian Academic Accounting Association, Annual Conference, Montreal.

46. Lobo G, Paugam L, Zhang, Casta J (2017) The Effect of Joint Auditor Pair Composition on Audit Quality: Evidence from Impairments Tests. Contemp Acc Res 34: 118-153.

47. Deng M, Dana T, Ye M (2014) Do Joint Audits Improve or Impair Audit Quality? J Acc Res 52: 1029-1060.

48. Libby R, Bloomfield R, Nelson M (2002) Experimental Research in Financial Accounting. Accounting, Organizations and Society 27: 775-810.

49. Liyanarachchi $\mathrm{G}$ (2007) Feasibility of using student subjects in accounting experiments: a review. Pac Acc Rev 19: 47-67.

50. Liyanarachchi G, Milne M (2005) Comparing the investment decisions of accounting practitioners and students: an empirical study on the adequacy of student surrogates. Accounting Forum 29:121-135.

51. Elliott W, Hodge F, Kennedy J, Pronk M (2007) Are MBA students a good proxy for nonprofessional investors. Acc Rev 82: 139-168. 
Citation: Ibrahim A, Badawy H (2018) Effect of Audit Quality on Non-Professional Investors' Decisions: Experimental Evidence from Egypt. Int J Account Res 6: 185. doi:10.4172/2472-114X.1000185 